\title{
Relaxin inhibits cardiac fibrosis and endothelial-mesenchymal transition via the Notch pathway [Corrigendum]
}

Zhou X, Chen X, Cai JJ, et al. Drug Des Devel Ther. 2015;9: 4599-4611.

On page 4600, the product type and source of the relaxin used in these experiments was missed from the 'Materials and methods' section.

Under the subheading 'Rat model of cardiac fibrosis' the second paragraph should read:

Rats were randomly divided into five groups (ten per group) for treatment: control; myocardial fibrosis (isoproterenol
[Iso]); and low-, middle-, and high-dose RLX $(0.2,2$, and $20 \mu \mathrm{g} \cdot \mathrm{kg}^{-1} \cdot \mathrm{day}^{-1}$, respectively). RLX was obtained from Peprotech, Rocky Hill, NJ, USA (product number 130-15). For the Iso-model, on days $1-6$, Iso $\left(5 \mathrm{mg} \cdot \mathrm{kg}^{-1} \cdot \mathrm{d}^{-1}\right.$; SigmaAldrich Co., St Louis, MO, USA) was injected subcutaneously in the rats. In the therapeutic groups, Iso administration was the same as in the Iso-model group, and RLX at different concentrations $\left(0.2,2.0\right.$, and $\left.20 \mu \mathrm{g} \cdot \mathrm{kg}^{-1} \cdot \mathrm{day}^{-1}\right)$ were injected at the same time as Iso injection and lasted for 6 days, then RLX injection was continued for another 8 days. The same volume of saline was injected for controls.
Drug Design, Development and Therapy

\section{Publish your work in this journal}

Drug Design, Development and Therapy is an international, peerreviewed open-access journal that spans the spectrum of drug design and development through to clinical applications. Clinical outcomes, patient safety, and programs for the development and effective, safe, and sustained use of medicines are the features of the journal, which

\section{Dovepress}

has also been accepted for indexing on PubMed Central. The manuscript management system is completely online and includes a very quick and fair peer-review system, which is all easy to use. Visit http://www.dovepress.com/testimonials.php to read real quotes from published authors. 